\title{
Kernos
}

Revue internationale et pluridisciplinaire de religion grecque antique

$34 \mid 2021$

Varia

\section{Beyond the Polis: Rituals, Rites, and Cults in Early and Archaic Greece (12th-6th Centuries BC)}

\section{Michael Anthony Fowler}

\section{OpenEdition}

\section{Journals}

Electronic version

URL: https://journals.openedition.org/kernos/3895

DOI: 10.4000/kernos.3895

ISSN: 2034-7871

\section{Publisher}

Centre international d'étude de la religion grecque antique

\section{Printed version}

Date of publication: 31 December 2021

Number of pages: $287-290$

ISBN: 978-2-87562-305-8

ISSN: 0776-3824

\section{Electronic reference}

Michael Anthony Fowler, "Beyond the Polis: Rituals, Rites, and Cults in Early and Archaic Greece (12th-6th Centuries BC)", Kernos [Online], 34 | 2021, Online since 31 December 2021, connection on 15 March 2023. URL: http://journals.openedition.org/kernos/3895 ; DOI: https://doi.org/10.4000/kernos. 3895

This text was automatically generated on 15 March 2023.

All rights reserved 


\title{
Beyond the Polis: Rituals, Rites, and Cults in Early and Archaic Greece (12th-6th Centuries BC)
}

\author{
Michael Anthony Fowler
}

\section{REFERENCES}

Irene S. LEMOS, Athena TSINGARIDA (eds.), Beyond the Polis: Rituals, Rites, and Cults in Early and Archaic Greece (12th-6th Centuries BC), Brussels, CReA-Patrimoine, 2019. 1 vol. $30 \times 21 \mathrm{~cm}, 304$ p. (Études d'Archéologie, 15). ISBN : 978-29-6020-292-2.

1 The co-edited volume under consideration presents the peer-reviewed proceedings of a homonymous conference held at the Free University of Brussels and the Royal Academy of Belgium in 2015. It opens with a general introduction by the editors to the topic of the conference and to its 17 constitutive papers. The contributions deal with ceremonial contexts and rituals of diverse kinds, which antedate, transcend, or develop beneath or independently of the polis and its institutions. The papers are arranged thematically into four sections: "Theoretical Considerations on Ritual Practices"; "Regional Cases I: Central Greece and the Peloponnese"; "Regional Cases II: The Aegean and Western Greece"; and "Bioarchaeological Approaches to Ritual Practices". The inclusion of zooarchaeological and archaeobotanical studies is especially welcome, as it enhances the volume's interdisciplinary appeal and demonstrates the critical value of long neglected categories of archaeological evidence for reconstructing ancient (religious) practices (here esp. in the case of the 'Ritual Zone' at Xeropolis-Lefkandi).

2 The first, theoretically oriented section features three essays that respond to the current state of scholarship on sanctuaries and cults in Late Bronze Age, Early Iron Age, and Archaic Greece and, as such, provides a useful analytical framework for the case studies that follow. With an emphasis on the organizational/institutional sense of the titular phrase Beyond the Polis, in his essay François de Polignac conducts a comparative 
analysis of select sanctuaries in Central Greece whose foundation and functions were not, perforce, the result of the top-down agency of a polis. Instead, such sanctuaries, situated at an interregional crossroads or passage, may have begun as 'central' or 'shared' places that enabled interaction of peoples of diverse origins and the formation of collective identities that surpassed that of a specific polis (e.g. 'interregional' elites) before falling under the sway of particular states and transforming into territorial markers. That the control and reach of these and other sanctuaries could vary over time leads de Polignac to caution against fixed categorizations like 'panhellenic' or 'local', which obscure other ways that sanctuaries could function in relation to their clientele, as well as to one another.

Through a comparative survey of the contexts, layouts, and degrees of accessibility of Palatial, Post-palatial, and Early Iron Age sanctuaries on the Greek mainland, Birgitta Eder argues that the question of (dis)continuity of cult places across the Late BronzeIron Age transition should be considered from a broader geographic perspective, accounting for "cycles of popularity" of sites "in the pace of changing societies" (p. 25). The A. finds, for example, that the most eloquent cases of cult continuity (and the formation of [supra]regional identities) are to be sought at sanctuaries situated outside settlements (along roads, at intersections, upon peaks), which were open to a wider demographic and afforded different, even rival groups a shared place of interaction that did not necessarily depend upon the hierarchical palatial systems for their administration (and survival).

4 In an important contribution, Matthew Haysom confronts a fundamental yet rarely addressed methodological question as it relates to the study of prehistoric religion and rituals: how to define terms of inquiry that are appropriate to the culture under study and to identify their traces in the archaeological record? Following a brief, critical overview of previous scholarship, Haysom proposes that the framework of anthropologist Clifford Geertz (1973) be adopted. The heuristic benefits of Geertz's framework are demonstrated through a case study of Karphi, where the number of identified religious spaces at Karphi is reduced to one: the 'temple'. The appearance of 'religious' paraphernalia outside this context can be considered alternatively either as the projection of symbolic references into aspects of everyday life or as the translation of the mundane into the religious sphere.

The series of regional case studies (sections 2 and 3) opens with Maria Mili's succinct comparative analysis of the votive habits at two Thessalian sanctuaries (of Athena Itonia at Philia and of Ennodia at Pherai) in the Geometric and Archaic periods. The A. emphasizes similarities among these and other Greek sanctuaries, in an effort to shed light on processes of identity formation taking place at supralocal levels. Mili observes that the votive profiles of both sanctuaries are rich in particular sartorial adornments and jewelry and short on figural objects, and contain a mixture of gendered objects, all of which distinguishes these sanctuaries from others. This suggests the development of a distinct "regional flavor" (p. 73) at these Thessalian sanctuaries, while the participation in the wider, contemporary Greek practice of durable votive offerings evinces the extra-regional awareness of their visitors.

6 The following two contributions (by Irene S. Lemos and Caroline Thurston) are initial reports on the excavations undertaken since 2005 in Region II of Xeropolis, wherein was uncovered an area containing a chronologically successive series of at least three structures (labeled A, B, and C; ranging from LH IIIC Early to the EIA [10 $0^{\text {th }}$ cent.]) with 
installations-most notably clay drums in the former two and stone platforms in the latter-and finds that suggest their function was non-domestic and non-funerary. Lemos hypothesizes that the two Late Bronze Age structures (A and B) housed distinct rituals (respectively, the exposition of objects [an early sort of trapezomata?], and commemoration of discrete feasting events) while, in the Early Iron Age, Structure C functioned as a venue for the exposition of objects; feasting appears to have taken place around the structures. While various ritual practices are traceable within the 'Ritual Zone', it remains unclear whether these activities were linked with a cult. Thurston's study of the terracotta finds from the 'Ritual Zone' arrives at a consonant conclusion: the comparative density of terracotta finds and the presence of rare or otherwise unattested types (some with a common aquatic association) distinguish this site from the rest of the Xeropolis and evince a distinct (votive?) habit.

Floris van den Eijnde revists the archaeological evidence associated with the Late Helladic 'Building B' at Eleusis to test, and ultimately validate, Michael Cosmopoulos' suggestion that this building-or more accurately the still visible (and partially restored?) vestiges thereof-functioned as a mythical "lieu de mémoire" in the context of the early cult of Demeter. In the latter half of the essay, van den Eijnde argues that the Hymn to Demeter preserves Early Iron Age Eleusinians' mythopoetic engagement with the site's Mycenaean remains in the broader context of intercommunal rivalry (particularly with Athens), by which the etiology of a distinct, 'poliadic' cult (in the sense advanced by de Polignac) and a distinct communal identity were forged through the invention of a shared past.

8 In light of evidence uncovered in more recent excavations conducted at the Late Archaic Westkomplex (the site of an EIA burial ground on the Kolonna Hill of Aegina), Gudrun Kelbinder-Gauss assesses, and cautiously affirms, the prevailing interpretation of the building complex as a venue for rituals associated with ancestor or hero veneration, including consumption of food and drink by a group with a restricted membership, perhaps based on kinship.

In view of their related attention to the commemoration of ancestral figures, the paper by Athena Tsingarida and Didier Viviers, which appears later in section 3, may be placed in conversation with Kelbinder-Gauss' contribution. Tsingarida and Viviers provide a preliminary report on the recently excavated Archaic-era building complex at the western edge of the North Necropolis of Itanos, which incorporated within it two earlier tombs (purposefully cleaned and restructured as cenotaphs) and accommodated several collective rituals carried out in connection with them, perhaps by a kinship or other corporate group seeking to achieve social cohesion during a period of Cretan history when the known mortuary record becomes taciturn (or 'austere'). The present reviewer looks forward to the final publication of the Archaic complex, which will hopefully clarify the relationship among the members of the small group who convened at this site and the respective ancestral 'owners' of the cenotaphs. For instance, why were the two cenotaphs segregated into separate spaces within the complex (courtyard D and room F)? Was this meant to maintain an important distinction between the ancestral figures (and by extension their respective descendants) even after they were unified within the overall complex? And, relatedly, what should we make of the different sacrificial/offertory installations-bothros and pyre pits in west courtyard D versus an altar in room $\mathrm{F}$-associated with the cenotaphs in the building's Archaic phase? 
10 The final paper of section 3, by Reine-Marie Bérard, is more obliquely related to the other papers and to the volume's theme of beyondness. It concerns the funerary domain yet focuses on the handling of the contemporary dead in a colonial context: the Southern and Western necropoleis of Archaic Megara Hyblaea. Bérard observes, inter alia, that children account for the great majority of tombs, which-in addition to the lack of sex-based distinctions in adult graves-leads Bérard to conclude that cemeteries functioned primarily practically (i.e. deposition of all dead irrespective of their identity or status) rather than symbolically (i.e. production/projection of socially stratified identities). According to this interpretation, the management of the necropolis would have been motivated by the same communitarian ideal as has already been proposed in the case of the city's urban planning.

11 The topic of continuity is reprised in Mary Voyatzis' presentation of major findings from the ongoing excavations at the sanctuary of Zeus on Mt. Lykaion and especially the ash altar. Detailed investigation of the altar has yielded evidence for continual votive and sacrificial activities from the Mycenaean era to the Hellenistic period, including-most remarkably-the practice of burnt animal sacrifices akin to the historical Greek thysia (esp. the frequency of heavily burnt ovicaprid femurs and patellas). Preliminary analysis of the ceramic material suggests that the site drew an ever-widening scope of Peloponnesian and 'West Greek' visitors over the transition from the Late Bronze Age to the Early Iron Age; this observation has led the authors to hypothesize that Lykaion may have been the prototype and inspiration for the raised ash altar that was subsequently introduced at the sanctuary of Olympia.

Ioannis Chalazonitis discusses the late seventh-century foundation of cults to Artemis or 'Artemis-like' deities at the northeast Aegean sites of Thasos, Neapolis, and Oisyme. He argues, on the basis of observed material similarities, that the cults at Neapolis and Oisyme followed closely upon that at Thasos and were probably established by Thasian settlers; yet, over the succeeding decades, these mainland sanctuaries developed distinct ritual practices and votive habits that suggest not just differences among the three cults but also the formulation of communal identities with varying degrees of distance/distinction from Thasos (and perhaps also reflecting the incorporation of elements derived from the indigenous Thracian culture?).

13 Irène Sanchez's and Alexandra Alexandridou's contributions both focus on the Cycladic islands. Sanchez treats the phenomenon of rituals performed at abandoned Cycladic sites, with a particular interest in ascertaining the size and social identity of the groups who took part in these activities from the Late Bronze Age into the Archaic period. She suggests that, from the Post-palatial era through the Early Iron Age, these rituals largely involved locals and were conducted on an occasional, individual/small scale that left modest archaeological traces; but from the Late Geometric period, abandoned sites received greater material investment, which probably reflects a cooperative/ communal initiative. Directing her attention to Early Iron Age presence at Despotiko, Alexandridou hypothesizes that the successive buildings $O$ and $\Xi$ correspond, respectively, to one of several dwellings within an extensive settlement that accommodated feasting, and a feasting venue with a more explicit cultic connection. If this interpretation is valid, from the Late Geometric to Early Archaic period, the earlier settlement gradually transformed into a sanctuary, seeing spaces and structures with mixed or overlapping uses (sacred and profane) replaced by ones exclusively dedicated 
to sacred/cultic ends, and acquiring a new status in the broader context of Parian synoecism.

The final, bioarchaeological section commences with Tatiana Theodoropoulou's discussion of the ritual use and significance of marine animals in the Early Iron Age. The essay, which principally addresses methodological concerns, is one of the few contributions to speak directly to the issues raised by Haysom, particularly with reference to the challenge of disambiguating the remains of mundane consumption from those which were involved in ritual or cult activities. This interpretative issue also arises mutatis mutandis in Alex D. Mulhall's analysis of the animal remains in the 'Ritual Zone': cf. the great similarity observed in the taxonomic makeup of bones found within the Zone and in other areas of Xeropolis. While it is generally difficult to ascertain the precise nature of the bone deposits, a few-e.g. the deer antlers in Structures A and C and a discrete deposit in Structure B of 14 bones representing as many as nine different wild and domestic species-are more easily attributable to ritual origins. Analogously to Muhall, Alexandra Livarda and Georgia Kotzamani remark that the plants identified in the 'Ritual Zone' are also encountered more generally in Xeropolis, with the notable exceptions of free-threshing wheat and perhaps the aromatic coriander (the former of which is documented in several Greek sanctuaries and thus may have been reserved for special, ritual use at Xeropolis).

The co-editors are to be congratulated for assembling a theoretically rich and analytically acute slate of papers. The chronological and geographic breadth represented in the volume should attract, and hopefully stimulate further interdisciplinary exchange between, scholars of prehistoric and historic Greece. Indeed, the great strength of the volume resides just as much in its contributors' advancement of our knowledge of the dynamic relationship between religion and identity formation from the collapse of the Mycenaean palaces to the Archaic period as it does in its articulation of new or still unresolved questions-questions which will doubtless inspire and guide the work of specialists for years to come.

\section{AUTHORS}

\section{MICHAEL ANTHONY FOWLER}

East Tennessee State University 